\title{
The Use of English in Teaching Science and Mathematics at Public Junior High School 1 Gorontalo
}

\author{
Hasanuddin \\ Universitas Negeri Gorontalo \\ hasanuddin@ung.ac.id
}

\begin{abstract}
The competitiveness in education is one of the important issues for developing quality of education in Indonesia. The government of Indonesia has made a decision about the criteria of national standard school, planning for international standard school, and international standard school. The international standard school requires English as a medium of instruction for science, mathematics, and core vocational subjects that need to be concerned in relating to the use of English language as a medium in the classroom interaction where teacher' talk and students' talk are understandable among others for educational instruction, and the role of the teachers to teach contents of science and mathematics. The implementation of teaching science and mathematics has some important indicators to be investigated. The objectives of the research are (1) to find out teacher interactional competence in teaching science and mathematics through English, (2) to find out learners interactional patterns that occur in teaching science and mathematics through English, and (3) to find out the roles of the teachers that reflect teaching approach or method in teaching science and mathematics through English. The research used qualitative approach and data were collected by using interview and direct observation to the teachers of science and mathematics who were teaching subject matters through English that are called subjects of the research. Data were analyzed qualitatively with ethnography of communication and discourse analysis. The research findings indicated that the teaching of science and mathematics were not maximally implemented because of a limited English language instruction and terms related to the contents of the teaching.
\end{abstract}

Key words: teaching, teacher interactional competence, learner interactional pattern, the role of the teacher

\section{INTRODUCTION}

Internationalization at all levels of education in Indonesia is aimed to achieve the vision of education as a quality and competitiveness. The government of Indonesia through the ministry of national education at a university level has proposed that public or private universities have to develop their regional and world rankings of university to be a world class university that characterized by the presence of international students, teaching and classroom interaction through English or other foreign languages, and international standard research, journals, and publishing. At the junior and high school levels, the ministry of national education has already planned to develop quality of education to national standard, planning for international standard, and international standard schools that indicate: (1) a curriculum should be international standard in accordance with an OECD member country, (2) using English as a medium of classroom interaction especially for teaching mathematics and science and core vocational subjects (Depdiknas, 2007).

The implementation of national education vision as a competitive education at every level of education in Indonesia became a philosophy of a quality of education by standardizing schools at national, planned international standard, and international standard schools. International standard schools are according to the criteria that the government and international partners have set up together. For instance, the quality of academic administration and management, process of student recruitment, curriculum and its implementation, human resources including teachers, facilities for education implementation.

The implications of the main tasks of teachers at international schools in more firmly again is to educate, teach, guide, direct, train, assess, and evaluate students with international standards. Some of the main tasks outlined in this school are as follows: (1) develop an international curriculum, (2) develop an international syllabus, (3) create lesson plans, (4) conduct a bilingual teaching by using one of foreign languages, especially in English and Indonesian, so teachers must have English language skills, and many more tasks at an international school.

RSBI (Rencana Sekolah Berstandar Internasional) Public Junior High School I Gorontalo SMP Negeri 1 Gorontalo has been stated by the government as RSBI that is located at central city of Gorontalo. This school has been developing international school requirements including management, curriculum, human resources, teaching and learning process, facilities, etc. For the RSBI school like SPMN 1 Gorontalo, it is still developing capacity to be an international standard school.

In actual condition of teaching mathematics and science at RSBI SMPN 1 Gorontalo according to pre research indicated the teachers of science and mathematics have already used English as a medium of classroom interaction in teaching and learning process. However, they 
have not been well performed because of (1) low interactional competence in teaching science and mathematics through English, (2) learners interactional patterns occur in teaching science and mathematics through English are not so helpful to facilitate learning activities, and (3) the roles of the teachers are not maximal to reflect teaching approach or method in teaching science and mathematics through English.

Interactional competence according to Richards and Lockhart (1994) is how teachers manage their interaction with the class in a way to allow all students in participating and interacting in the classroom that consists of several dimensions of classroom behavior: (1) knowing the etiquette of classroom interaction, (2) knowing the rules for individual and collaborative work, (3) knowing when to ask and answer questions, (4) knowing how and when to assistance or feedback in completing a task, and (5) knowing appropriate rules for displaying knowledge.

Teaching science and mathematics through English is also related to the importance of language teachers in the classroom communication. Nunan (1989) has investigated issues related to types of teacher talk, speech modifications made by teachers, instructions and explanation, types and number of questions asked and error correction. Teachers modify their speech to make the language easier to comprehend, and in turn, to help the learner to understand and apply teaching materials for instance science and mathematics. The teacher also instructs and explains the teaching materials to students and therefore the teacher and students develop their interactional patterns. For instance, teacher - students interactional patterns, students- teacher interactional patterns, etc. Besides, the teacher also asks questions for clarification and check students' understanding.

The implementation of teaching science and mathematics has some important indicators to be investigated. The focus of investigation would be on (1) how teachers interactional competence occur in teaching science and mathematics through English, (2) how learners interactional patterns occur in teaching science and mathematics through English, and (3) what roles of the teachers that reflect teaching approach or method in teaching science and mathematics through English. The objectives of the research are: (1) to find out teacher interactional competence in teaching science and mathematics through English, (2) to find out learners interactional patterns that occur in teaching science and mathematics through English, and (3) to find out the roles of the teachers that reflect teaching approach or method in teaching science and mathematics through English.

The significance of this study are: (1) For the teacher, the result of this study is hoped to give contributions to teachers of mathematics and science especially interactional competence in teaching and learning process and accommodate students interactional patterns by using
English, (2) For the school, the result of this study is hoped to give the description about the teachers' ability in interactional competence and the teachers' roles in teaching and learning process by using English. By knowing the teachers' ability in interactional competence and teachers' roles, the school is hoped to make a plan how to develop quality of teachers and education for all.

\section{METHODS}

This research used qualitative and descriptive to investigate the teaching mathematics and science through English (Sugiono, 2008; Nunan, 1992, p.91, Nunan, 1989, \& Denzin, 1978). The data were the use of English in the classroom interaction when the teachers taught mathematics and science. The data were collected by using direct observation and interview. The researcher observed directly to the teachers of mathematics and science when they were teaching mathematics and science through English at SMPN 1 Gorontalo. There were three teachers in science class were observed, and there were three teachers in mathematics were observed. The observation was done for 5 sections and each section consisted of 45 minutes for presentation. Interview was also used to teachers of science and mathematics for supporting data of classroom interaction. Data were finally analyzed qualitatively (Marshall \& Rossman, 1989) by transcribing data, classifying data, sorting data, interpreting data according to research focus, and finally drawing a conclusion.

\section{RESULTS AND DISCUSSION}

\subsection{Teachers' Interactional Competence in Teaching Science and Mathematics through English}

Research findings indicate that teachers interactional competence in teaching science and mathematics through English were not maximally implemented because of some factors: (1) teachers can manage their class and their interaction but students have a limited opportunity to participate, (2) limited English language terms related to science and mathematics to be used by both teachers and students, and (3) there was no guide book for both teachers and students when they were learning science and mathematics.

The teachers can manage their class when they were teaching science and mathematics but students have a limited opportunity to take a part in the classroom interaction. The teachers of science and mathematics dominate their talk. The students would take a part if the teachers gave them opportunity to do something according to their instruction. This is also because of the cultural background of the learners that they cannot take a turn without the teacher's permission.

As teachers of science and mathematics, they have to know well about how to know the rules for individual and collaborative work. In the teaching of science and mathematics, the teachers dominated teaching learning 
process so the students have no individual work and collaborative work. There was less opportunity for the students to take turns and the students gave passive participation. Therefore, in the future students would be more active in learning with individual work and cooperative work in learning science and mathematics. According to Tomlinson (2004) personal growth for professional development is a part of developing quality of education.

Related to the teacher's competence in managing the classroom, it is found that the teachers have managed the class. The teachers managed the class before she started to teach. Related to the using English in teaching and learning process, the teacher used it around the class. In teaching and learning process, the teachers explained the material by using LCD. After that, the teacher gave the task to the students. Related to interaction or communication in the class, the researcher found that the teacher can build the communication when they were study.

\subsection{Learners' Interactional Patterns Occurred in} Teaching Science and Mathematics through English

Based on the observations that have been made, it was found that there had been interaction in the classroom during the learning process by using English. Interaction in the classroom starts with teachers of the early events, activities continued with the opening of the core activities of learning and end with the closing activities. All stages in this learning process by using English.

In the warm-up activity, the teacher started in the classroom interaction with learners greeting. In addressing learner,s teachers began to greet their students out early activities, learners had begun to get used to the interaction during the learning. After that, the teachers began to start asking the material learners have learned in the previous meetings. In this activity, teacher asked the previous material to learners by their names.

The second stage is the core stage of the learning process. At this stage, the teacher began to explain material to learners. In this stage, the teacher initially displayed a video related to the material. The video was displayed by using English as a language of instruction. After seeing the video show, the teacher began to give some questions regarding to the video. The all learners were asked to do the tasks that were assigned by the teacher. They were given tasks that teachers using the English language. After the task has been done, the teacher began to explain the material that became the main topic at the meeting. In the matter explained, teachers used the English language. The last stage in the learning we observed is the closing activity. Within this activity, the teacher concluded that the material has been studied together with learners. Before the teacher ended activities on that day, the teacher gave the homework to their learners.

According to the stages of the teaching it was found that the dominant interactional patterns occurred were the teacher - learner interactional patterns, teacher- learners interactional patterns, and teacher - all learners interactional patterns. Besides, learners-teacher interactional patterns and learner-learners or learners-learner interactional patterns were not found.

Some basic considerations have been paid attention in the classroom interaction. Allwright and Bailey (1991) stated some factors have been considered like (1) who has to speak (participants), (2) what the talking about (topics), (3) what will participants do when they have opportunity (task), (4) what situation should be created (tone), and (5) what language code would be used.

The dominant interactional patterns occurred were teacher-learners that indicate that learners have less opportunity to take turn in the classroom communication. Therefore, learners are passive learning because the teacher dominates the opportunity to speak and in turn, they cannot express their willingness and practice their communication in the classroom. They are also difficult to develop background knowledge and procedural knowledge where learners integrate bottom-up and top-down processing, and in their ability to draw inference of the meaning of new words.

Richards and Lockhart (1994) described 6 different interactional patterns. They are (1) task-oriented students that are generally highly competent and successful in completing academic tasks and they enjoy school and learning, (2) phantom students that may not often be noted or heard in the classroom, and however, they are participate actively in lesson only infrequently, (3) social students that place a high value on personal interaction and they are competent in accomplishing classroom tasks and enjoy tutoring others in the class, (4) dependent students who need the teacher's support and guidance to complete class tasks, (5) isolated students that set themselves apart from others and withdraw from classroom interaction, and they avoid learning situation by learning away from activities, and (6) alienated students that react against teaching and learning and are often hostile and aggressive.

\subsection{Roles Reflecting a Teaching Approach or Method in Teaching Science and Mathematics through English}

Talking about the role of teachers in the learning process, it involves classroom setting, to guide and motivate students. The teachers' roles have been seen in the learning process. In the role of teachers as mentors, teachers always came to seat students and provide guidance about the task or the material. They discussed roles of teachers in the context of teaching science and mathematics may also be influenced by the approach or methodology that the teachers used. It is found that the teachers (1) communicated clearly by giving accurate direction, specifying tasks and measurement, presenting new information by explaining, outlining, summarizing, reviewing, (2) obtained and managed engagement by maintaining task focus, pacing instruction 
appropriately, and communicating expectation for successful performance, (3) monitored progress by reviewing work frequently, and (4) provide immediate feedback by informing students when they are successful, and giving information about how to achieve success.

To maximize roles of the teachers in teaching science and mathematics is needed to train the teachers of physics, biology, and mathematics about a guidance of instructional terms related to English language instruction, and terms related to contents of physics, Biology, and mathematics themselves. These are main problems faced by the teachers that have to use the English as a medium of instruction in teaching science and mathematics. Breen and Candlin (1980 p.92) stated that characterize the target competence to communicate involve the learners in the sharing and negotiating meaning.

Many ways have been made to overcome the problems faced by students and teachers in the learning process. For the teachers themselves, the school has been conducting training programs on the use of English in the learning process. In addition, teachers themselves to improve themselves by always studying learning handbook. For students, the way they do to overcome the problem of learning is that they try to find a guide book that uses the language of the Indonesian language. They find this book just to support their understanding of the material provided by teachers using the English language. However, the use of English remains the most important. In addition, for smooth their mastery of English, they also take courses outside school hours. Thus, the main problem is the use of English in learning science and mathematics can be overcome.

\section{CONCLUSION}

Teachers interactional competence in teaching science and mathematics through English were not maximally implemented because of some factors: (1) teachers can manage their class and their interaction but students have limited opportunity to participate, (2) limited English language terms related to science and mathematics to be used by both teachers and students, and (3) there was no guide book for both teachers and students when they were learning science and mathematics. The dominant interactional patterns occurred were the teacher - learner interactional patterns, teacher- some learners' interactional patterns, and teacher - all learners' interactional patterns. While learners-teacher' interactional patterns and learnerlearners' or learners-learner' interactional patterns were not found. Roles of teachers in the context of teaching science and mathematics may also be influenced by the approach or methodology that the teacher follows. It is found that the teachers (1) communicated clearly by giving accurate direction, specifying tasks and measurement, presenting new information by explaining, outlining, summarizing, reviewing, (2) obtained and managed engagement by maintaining task focus, pacing instruction appropriately, and communicating expectation for successful performance, (3) monitored progress by reviewing work frequently, and (4) provided immediate feedback by informing students when they are successful and giving information about how to achieve success.

\section{REFERENCES}

Allwright, D. \& Bailey, M. K.(1991). Focus on the language Classroom: An Introduction to Classroom Research for Language Teachers. New York: Cambridge University Press.

Breen, M., \& Candlin, C. N. (1980). The essentials of Communicative Curriculum in Language Teaching. Applied Linguistics. 1,(2): 89-122.

Denzin, N. K. (1978) The Research Act: A Theoretical Introduction to Sociological Methods; New York: McGraw-Hill Book Company.

Depdiknas, (2007) Sistem Penyelenggaraan Sekolah Bertaraf Internasional (SBI) Untuk Pendidikan Dasar dan Menengah : Jakarta

Depdiknas, (2007). Panduan Penyelenggaraan Rintisan Sekolah Bertaraf Internasional (RSBI) Untuk Sekolah Menengah Pertama (SMP) : Jakarta

Depdiknas, (2007). Sistem Penyelenggaraan Sekolah Bertaraf Internasional (SBI) Untuk Pendidikan Dasar dan Menengah :Jakarta

Marshall, C. \& Rossman, G. B. (1989). Designing Qualitative Research. New York: Sage Publication.

Nunan, D. (1989). Undertstanding language Classroom.A Guide for Teacher-initiated Action. Now York, London: Prentice Hall International English Language Teaching.

Nunan, D. (1992). Research Methods in Language Learning. Richards, J. C. \& Lockhart, C. (1994). Reflecting Teaching in Second Language Classroom. Cambridge: Cambridge University Press.

Sugiyono, (2008). Metode Penelitian Kuantitatif, Kualitatif, dan $R \& D$. Alfabeta: Bandung

Tomlinson, H. (2004). Educational Leardership: Personal Growth for professional Development. London: Sage Publication. 